\title{
Characterization Of A Novel Hydrolytic Enzyme Producing Thermophilic Bacterium Isolated From The Hot Spring Of Azad Kashmir-Pakistan
}

\author{
Sana Zahoor ${ }^{1 *}$; Huhammad Mohsin Javed ${ }^{2}$; Masroor Ellahi Babarl'. \\ ${ }^{1}$ Virtual University of Pakistan - Department of Molecular Biology, Lahore, Pakistan; ${ }^{2}$ GC University, Lahore - \\ Institute of Industrial Biotechnology, Lahore, Pakistan.
}

\begin{abstract}
A thermophilic bacterium (TP-2) was isolated from the Tatta Pani hot spring in Azad Kashmir and was characterized using phenotypic and genotypic characters. The strain developed cream colored, round, smooth, flat and slimy colonies while the cells were Gram positive rods that ranged in size from about 2.1-3.6 $\mu \mathrm{m}$ to $0.2-0.3 \mu \mathrm{m}$ in width. Sequence analysis of its 16S rRNA gene showed that isolate TP-2 had 89\% homology with Geobacillus debilis. It grew within $\mathrm{pH}$ range of 5.5 to 8.5 with optimum growth at $\mathrm{pH}$ 7.0. The isolate showed optimum growth at $65^{\circ} \mathrm{C}$ and gave positive results for gelatin hydrolysis (GEL), ortho nitrophenyl- $\beta$-D-galactopyranosidase (ONPG), and nitrate production and produced acid from sucrose, glucose and maltose. It utilized glucose, fructose, maltose, lactose, sucrose, xylan, starch, filter paper and carboxymethylcellulose as sole carbon source. Isolate TP-2 produced significant amount of industrially important enzymes i.e. extracellular $\alpha$-amylase, CMCase, FPase, Xylanase, Protease and Lipase and intracellular CMCase and FPase.
\end{abstract}

Keywords: Tatta Pani, characterization, enzyme production, Geobacillus

\footnotetext{
${ }^{1}$ Authors for correspondence: azzamohamed99@yahoo.com
} 


\section{INTRODUCTION}

Microorganisms occupy all possible sites in which life survives, ranging from ideal environments for growth and reproduction to those signifying extreme environments. Extremophiles are adapted to live and grow in conditions like extreme salinity, temperature, $\mathrm{pH}$ and absence of oxygen. Thermophilic bacteria grow optimally at temperatures ranging from $45^{\circ} \mathrm{C}$ to $70^{\circ} \mathrm{C}$, and hence, it is likely to isolate them from numerous habitats like deep-sea hydrothermal vents, deep ocean-basin cores, petroleum reservoirs and artificially hot environments like fermented compost (Rahman et al. 2004; Lebedinsky et al. 2007). One of the natural habitats of the thermophilic bacteria is the hot spring. Hot springs are springs that are geothermally heated. Hot springs are located all over the earth, on all continents and even beneath the seas and oceans (Kauze et al. 2006).

Thermophiles have gained a great consideration since they are not usually denatured at high temperature, yet they are active at elevated temperature (Lee et al. 1999; Beg et al. 2000). Thermostable enzymes, isolated chiefly from thermophilic microorganisms, are commercially important because of their inherent stability that is maintained under harsh industrial processes conditions as well as benefits for accomplishing the procedures at high temperature (Demirjian et al. 2001).

In recent times, molecular phylogenetic methods utilizing the small-subunit rRNA gene have been used to study the bacterial diversity of varied hot springs (Reysenbach et al. 2000). Thermophilic bacteria have been characterized by phenotypic and genotypic means from numerous geothermal regions of the World, comprising Italy (Maugeri et al. 2001), Turkey (Gul-Guven et al. 2008), Bulgaria (Derekova et al. 2008), Iceland (Marteinsson et al. 2001), Yellowstone National Park (Boomer et al. 2009), China (Lau et al. 2009), India (Sharma et al. 2009) and Greece (Sievert et al. 2000).

Tatta Pani hot spring located in Azad Kashmir, Pakistan has not been explored yet from the microbiological aspects. The objective of this work was to isolate and characterize thermophilic bacteria from Tatta Pani hot spring using genotypic and phenotypic methods and to check the biotechnological potential of the isolates.

\section{MATERIALS AND METHODS}

\section{SAMPLE COLLECTION}

Water samples were collected separately in sterile thermal glass containers and in aseptic culture tubes containing LB medium $(1 \% \mathrm{NaCl}, 0.5 \%$ yeast extract, $1 \%$ tryptone, $\mathrm{pH}: 7.0)$. These tubes were placed into the water in the same place for two hours and taken to the lab for additional processing. In-situ (temperature) and ex-situ (pH, EC, soluble anions and cations) analysis of water samples was carried out to characterize the hot springs (Khalil et al. 1998).

\section{ISOLATION OF BACTERIAL STRAINS}

Thermophilic bacteria were isolated through serial dilution method. Water sample $(100 \mu \mathrm{L})$ was added to the $\mathrm{LB}$ media and incubated at $65^{\circ} \mathrm{C}$. Pure culture was obtained by repeated streaking on LB agar plates followed by incubation at $65^{\circ} \mathrm{C}$ (Khalil et al. 1998).

\section{MORPHOLOGICAL CHARACTERIZATION}

Colony morphology characteristics of isolates were observed from $48 \mathrm{~h}$ culture on LB agar with respect to color, shape, margin, internal structure, elevation and configuration. Cell characteristics of isolate were studied by Gram's staining. Scanning electron microscopy was done commercially from University of Karachi.

\section{PHYSIOLOGICAL CHARACTERIZATION}

Optimum temperature for growth was determined by incubating the isolate in LB medium at different temperatures $\left(30-90^{\circ} \mathrm{C}\right)$ with $5^{\circ} \mathrm{C}$ interval. Optimum $\mathrm{pH}$ was determined by incubating the isolate overnight at $65^{\circ} \mathrm{C} \pm 1{ }^{\circ} \mathrm{C}$ by altering the initial $\mathrm{pH}$ of the LB medium from 4.0 to 10 with either $1 \mathrm{~N}$ $\mathrm{NaOH}$ or $1 \mathrm{~N}_{3} \mathrm{PO}_{4}$. The ability of the isolate to grow at different $\mathrm{NaCl}$ concentration was examined by incubating the isolate in $\mathrm{LB}$ medium (pH: 7.0) containing different amount of $\mathrm{NaCl}$ ranging from $0-5 \%$ (w/v). Growth was checked by measuring optical density (O.D.) at $600 \mathrm{~nm}$ using spectrophotometer (Nair and Surendran 2004).

Study of utilization of different carbon sources by the isolate was also checked. Mineral salts broth $\left(0.02 \% \quad \mathrm{MgSO}_{4} \cdot 7 \mathrm{H}_{2} \mathrm{O} ; \quad 0.25 \% \quad \mathrm{NaCl} ; \quad 0.001 \%\right.$ $\mathrm{FeSO}_{4} \cdot 7 \mathrm{H}_{2} \mathrm{O} ; 0.1 \%\left(\mathrm{NH}_{4}\right)_{2} \mathrm{SO}_{4} ; 0.15 \% \quad \mathrm{KH}_{2} \mathrm{PO}_{4}$; $\mathrm{pH}: 7.0)$ with $1 \%$ of different carbon sources, like sucrose, maltose, lactose, fructose, glucose, carboxymethylcellulose (CMC), xylan, starch, 
wheat bran extract and filter paper $(0.05 \mathrm{~g})$ was added to test tubes. These were inoculated with overnight grown culture $(20 \mu \mathrm{L})$ of the isolate followed by incubation at $65^{\circ} \mathrm{C}$ for $48 \mathrm{~h}$. Growth of the culture was determined by measuring the optical density at $600 \mathrm{~nm}$ using spectrophotometer.

\section{BIOCHEMICAL CHARACTERIZATION}

Oxidase test, catalase test and QTS-20 tests were performed following the method of Wiegel and Ljungdahl (1981), Tarrand and Groschel (1982) and Macfaddin (2000).

\section{MOLECULAR CHARACTERIZATION}

Genomic DNA was isolated after Kronstad et al. (1983). 16S rRNA gene was amplified by PCR using the following primers

\section{"9F 5'-GAGTTTGATCCTGGCTCAG-3'}

1510R 5'-GGTTACCTTGTTACGACTT-3'”

PCR reaction was carried out in a $50 \mu$ reaction mixture, using DNA $(1 \mu \mathrm{l} ; 50 \mathrm{ng})$, primers $(1 \mu 1$ e ach; $10 \mu \mathrm{M})$, dNTPs $(5 \mu \mathrm{l} ; 2.5 \mathrm{mM})$, PCR buffer ( $5 \mu \mathrm{l}$; IX), magnesium chloride $(5 \mu \mathrm{l} ; 25 \mathrm{mM})$ and Taq polymerase $(1 \mu \mathrm{l} ; 2.5 \mathrm{U})$. Initial denaturation of template was carried at $94^{\circ} \mathrm{C}(5 \mathrm{~min})$, followed by 35 cycles of $94^{\circ} \mathrm{C}(30 \mathrm{sec}), 54^{\circ} \mathrm{C}(30 \mathrm{sec})$ and $72^{\circ} \mathrm{C}$ $(90 \mathrm{sec})$ and one final cycle of extension at $72^{\circ} \mathrm{C}$ (10 $\mathrm{min}$ ). The PCR product was analyzed by agarose gel electrophoresis (1\%). The PCR product was excised from the gel and purified using Novagen spin prep gelmelt kit. The purified 16S rRNA gene was sequenced using 3130xl Genetic Analyzer. Sequence database similarity searches of the 16S rRNA gene sequence were done using the BLAST tool of GenBank. Alignment of 16S rRNA gene sequences was done using software Clustal W and observed by Jalview. Phylogenetic analysis was done using neighbor-joining method using the software MEGA 5.0 (Saitou and Nei 1987; Altschul et al. 1990; Thompson et al. 1994; Waterhouse et al. 2009). The stability of relationships was evaluated by carrying out bootstrap analysis of the neighbor-joining data based on 1000 resamplings.

\section{NUCLEOTIDE SEQUENCE ACCESSION NUMBER}

The 16S rRNA gene sequence of isolate TP-2 has been submitted in the GenBank with accession no. JQ284017.

\section{BIOTECHNOLOGICAL POTENTIAL}

Production of intracellular and extracellular enzymes was studied by incubating the isolate in different media reported by Mandels and Reese (1957), Srivastava and Baruah (1986), Chen et al. (2004), Lee et al. (1999), Sharma et al. (2007) and Kim et al. (1998) for the production of CMCase \& FPase, $\alpha$-amylase, protease, lipase, xylanase and phytase, respectively.

\section{Extraction of Extracellular and Intracellular Enzyme}

Following incubation for particular time interval, the fermented broth was centrifuged at 10,000 rpm $\left(4^{\circ} \mathrm{C}\right)$ for $15 \mathrm{~min}$. The supernatant obtained was utilized as extracellular enzyme. After centrifugation of the fermented broth, the cells were washed two times with $0.85 \% \mathrm{NaCl}(5 \mathrm{ml})$. The wet weight of the pellets was recorded and the pellets were placed at $-20^{\circ} \mathrm{C}$ before sonication. Frozen cells were thawed in potassium phosphate (50 $\mathrm{mM})$-EDTA (5 mM); pH: 7.0 buffer and the final cell concentration was kept at $20 \%$ wet weight/volume and then cells were broken by sonication on ice, using sonicator UP 400S at 70 amplitude for 30 cycles ( $30 \mathrm{sec}$ on/50 sec off). The mixture was centrifuged at $12,000 \mathrm{rpm}$ for $10 \mathrm{~min}$ at $4^{\circ} \mathrm{C}$ and the supernatant was utilized as intracellular enzyme.

\section{Enzyme Assay}

CMCase, $\alpha$-amylase, FPase, Lipase, protease, xylanase and phytase were estimated by the methods of Mandels et al. (1976), Rick and Stegbauer (1974), Ghose (1987), Mustranta (1992), McDonald and Chen (1965), Bailey et al. (1992) and Harland and Harland (1980) and Heinonen and Lahti (1981), respectively.

\section{STATISTICAL ANALYSIS}

Significance difference among replicates was shown in the form of probability $(p \leq 0.05)$ values using the software Costat (Snedecor and Cochrane 1980).

\section{RESULTS AND DISCUSSION}

Tatta pani is located in Kotli, Azad Kashmir (Pakistan) and Tatta Pani hot springs are positioned on the right bank of the river Poonch and can be approached from Kotli by covering a distance of 26 $\mathrm{km}$. Heat produced due to the occurrence of sulphur in Patala shales, friction alongside the Main Boundary Thrust and deep circulation of meteoric water underneath the surface is the possible cause of heat giving rise to hot springs in Tatta Pani, Azad 
Kashmir. In-situ measurements of temperature showed that the hot spring had temperature ranging from $79-86^{\circ} \mathrm{C}$. The hot spring had nearly neutral $\mathrm{pH}$ of 6.93. Khan et al. (1999) noted $\mathrm{pH}$ and temperature $1.70-1.86$ and $56-60^{\circ} \mathrm{C}$, respectively for these hot springs. Ex-situ characterization of water sample was done to determine the chemical composition of the hot spring (Table 1). The key cation in the Tatta Pani hot springs was found to be $\mathrm{Na}^{+}(208 \mathrm{mg} / \mathrm{L})$. EC value and TDS were recorded to be $462.6 \mu \mathrm{S} / \mathrm{cm}$ and $231.3 \mathrm{mg} / \mathrm{L}$, respectively. Khan et al. (1999) also stated $\mathrm{Na}^{+}$as the major ion in Tatta Pani hot spring, having concentration of 110 to $120 \mathrm{ppm}$. Total dissolved solids (TDS) and electrical conductivity (EC) were found to be 3911 to $4183 \mathrm{ppm}$ and 7020 to $9560 \mu \mathrm{S} / \mathrm{cm}$, respectively. Khan et al. (1999) study displayed a little variation in the water characterization results, they recorded low $\mathrm{pH}$ and temperature and higher TDS and EC values as compared to the current findings. This variation might be due to the difference in time period of study and due to the change in concentration of various ions and amount of sulfur that resulted in shift in $\mathrm{pH}$ from extremely acidic to neutral. The change in temperature detected may be because of different sampling points (distance from the source) or this change might be because of the earthquake that occurred in 2005.

Table 1: Composition of water in Tatta Pani hot spring

\begin{tabular}{lc}
\hline Type of Study & Result \\
\hline $\mathrm{Mg}^{+2}(\mathrm{mg} / \mathrm{L})$ & 0.91 \\
$\mathrm{~K}^{+}(\mathrm{mg} / \mathrm{L})$ & 2.9 \\
$\mathrm{Na}^{+}(\mathrm{mg} / \mathrm{L})$ & 208 \\
$\mathrm{Ca}^{+2}(\mathrm{mg} / \mathrm{L})$ & 4.5 \\
$\mathrm{Cl}^{-}(\mathrm{mg} / \mathrm{L})$ & 58.3 \\
$\mathrm{HCO}_{3}^{-}(\mathrm{mg} / \mathrm{L})$ & 0.71 \\
$\mathrm{CO}_{3}^{-2}(\mathrm{mg} / \mathrm{L})$ & 0.05 \\
$\mathrm{NO}_{3}{ }^{-1}(\mathrm{mg} / \mathrm{L})$ & 26.23 \\
$\mathrm{TDS}(\mathrm{mg} / \mathrm{L})$ & 231.3 \\
$\mathrm{~S} . \mathrm{A} . \mathrm{R}$ & 23.31 \\
$\mathrm{COD}(\mathrm{mg} / \mathrm{L})$ & 8.2 \\
$\mathrm{BOD} 5(\mathrm{mg} / \mathrm{L})$ & 16.9 \\
$\mathrm{Temperature}\left({ }^{\circ} \mathrm{C}\right)$ & $79-86$ \\
$\mathrm{EC}(\mu \mathrm{s} / \mathrm{cm})$ & 462.6 \\
pH & 6.93 \\
\hline
\end{tabular}

A thermophilic bacterium (TP-2) was isolated from Tatta Pani hot spring in Azad Kashmir. Single colonies were identified and the pure culture was isolated by repeated streaking on LB agar plates incubated at $65^{\circ} \mathrm{C}$. Colony morphology characteristics were examined from over $48 \mathrm{~h}$ culture on LB agar. Colonies were flat, cream colored and slimy with smooth margins while the cells were Gram positive rods (Fig. 1). Geobacillus sp. strain GWE1 formed white, convex and circular colonies while cells were gram positive rods (Daniela et al. 2013). Geobacillus sp. NMS2 isolated from water and soil samples from a hot spring in Sri Lanka formed yellow colored, round, convex and smooth colonies while the cells were rod shaped that stained positive with Grams staining (Mathew and Rathnayake 2014). Geobacillus thermoleorans strain Rekadwadsis isolated from hot spring in Unkeshwar formed light yellow, circular, convex and smooth colonies whereas the cells were long Gram positive rods (Rekadwad 2015).

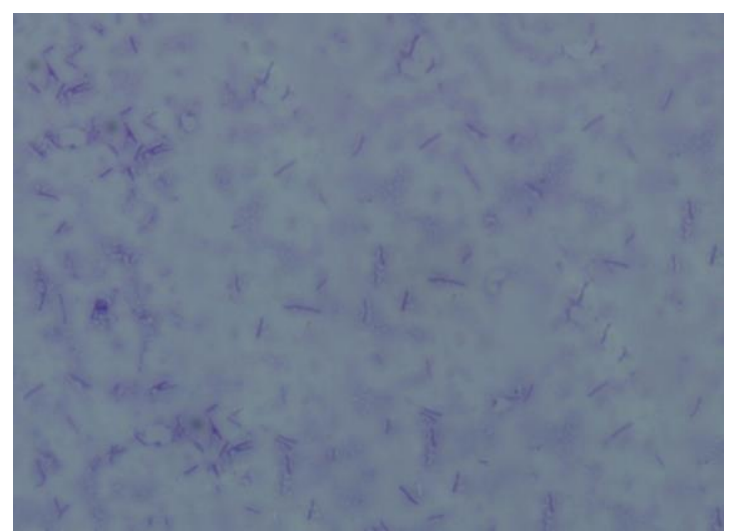

Figure1: Gram's staining of the isolate TP-2

Scanning electron microscopy results showed that the cells have smooth surface and ranged in size from $0.2-0.3 \mu \mathrm{m}$ in width to $2.1-3.6 \mu \mathrm{m}$ in length (Fig. 2). The length and diameter of cells of $G$. debilis, $G$. thermoglucosidasius and $G$. stearothermophilus ranged in size from 1.0-14.2 $\mu \mathrm{m}$ to $0.5-1.0 \mu \mathrm{m},<3.0 \mu \mathrm{m}$ to $<0.9 \mu \mathrm{m}$ and $2.0-3.5$ $\mu \mathrm{m}$ to $0.5-0.9 \mu \mathrm{m}$, respectively (Banat et al. 2004; Nazina et al. 2001; Sung et al. 2002). The length and diameter of cells of Geobacillus sp. strain GWE1, Geobacillus sp. NMS2, Geobacillus thermoleorans strain Rekadwadsis ranged in size from 8.0 to $0.8-1.0 \mu \mathrm{m}, 8-10$ to $1 \mu \mathrm{m}$ and $6.0-1.0$ $\mu \mathrm{m}$, respectively (Daniela et al. 2013; Mathew and Rathnayake 2014; Rekadwad 2015) 


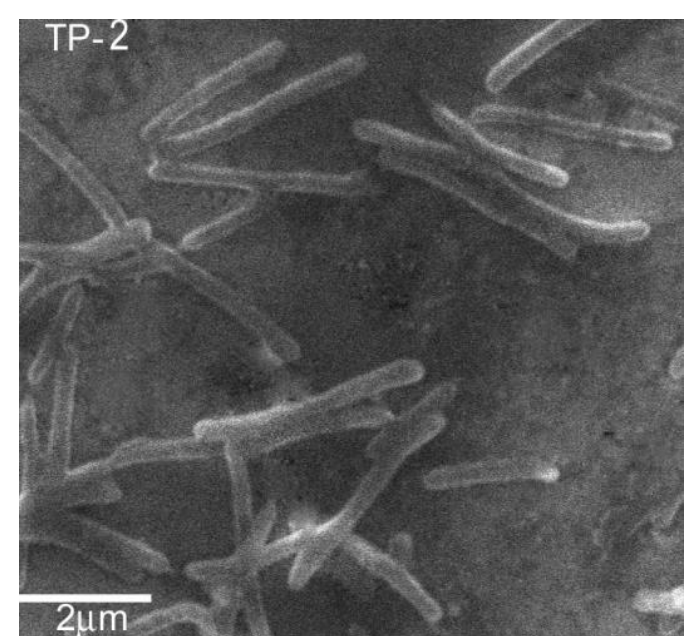

Figure 2: Scanning Electron Micrograph of isolate TP-2

Physiological and biochemical characters are significant as they give indications for selection of efficient strains for additional studies principally of applied value. Various range of $\mathrm{pH}(4.0-10)$ was tested to record the $\mathrm{pH}$ optimal for the growth of the isolate (Fig. 3). Maximum growth of isolate (TP-2) was recorded at $\mathrm{pH}$ 7.0. The isolate grew at $\mathrm{pH} 5.5$ to 9.0 while no growth was observed below $\mathrm{pH} 5.5$ and above 9.0. The isolate was able to survive at both slightly alkaline and acidic environments. Though the isolate preferred a neutral $\mathrm{pH}$ range, it adopted itself to survive at slightly basic and acidic $\mathrm{pH}$ conditions in the environment. Sharma et al. (2009) isolated Geobacillus spp. from the Soldhar hot spring site (India) that can tolerate $\mathrm{pH}$ range of 4.0-11. Thermophilic bacteria that grew well at $\mathrm{pH}$ ranging from 7.5-8.5 were isolated from the hot springs of Saudi Arabia (Khalil 2011). Geobacillus sp. SG 01 displayed optimum growth at $\mathrm{pH} 7.0$ while no growth was observed at $\mathrm{pH}$ values higher than 9.5 (Yang et al. 2013 ). Geobacillus pallidus p26 isolated from Pasinler hot spring, Erzurum, Turkey grew optimally at $\mathrm{pH} 7.5$ (Celik et al. 2014). Geobacillus sp. 12AMOR1 exhibited growth within the $\mathrm{pH}$ range of 5.5-9.0 with optimal growth within the wide $\mathrm{pH}$ of $6.5-8.0$ (Wissuwa et al. 2016).

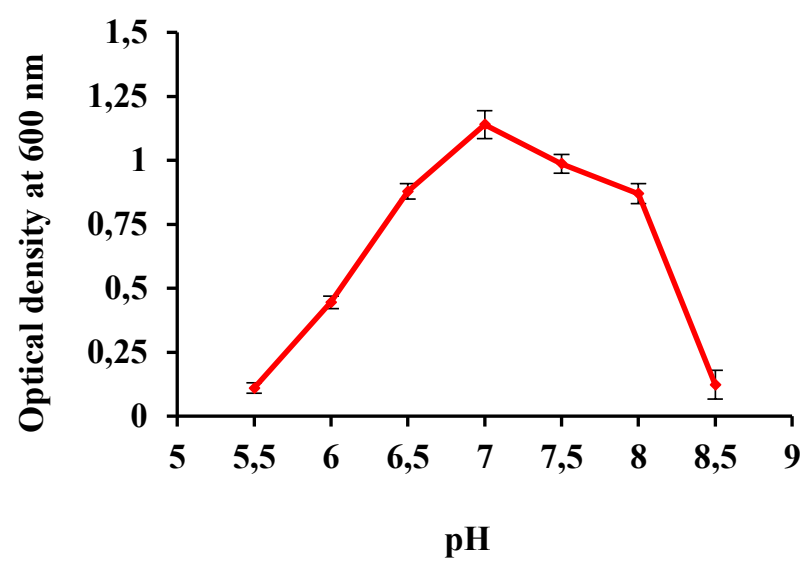

Figure3: Effect of $\mathrm{pH}$ on the growth of isolate TP-2. \pm indicates the standard deviation among the three parallel replicates.

Minimum, optimum and maximum growth temperature for the isolate was noted by incubating the isolate at different temperature $\left(30-90^{\circ} \mathrm{C}\right)$. The isolate displayed good growth within temperature range of $50-65^{\circ} \mathrm{C}$ with maximal growth observed at $65^{\circ} \mathrm{C}$ (Fig. 4). No growth was observed below $40^{\circ} \mathrm{C}$ while the upper limit for growth with respect to temperature was around $75^{\circ} \mathrm{C}$. The temperature specificity of the isolate indicated that it is thermophilic in nature since it required $65^{\circ} \mathrm{C}$ for optimum growth and was unable to grow outside the temperature range of $40-75^{\circ} \mathrm{C}$. Thermophilic bacteria that showed good growth between $45-85^{\circ} \mathrm{C}$ were isolated from hot springs of Fiji (Narayan et al. 2008). G. thermoglucosidasius grew within the temperature range of $37-68^{\circ} \mathrm{C}$ (Nazina et al. 2001). Geobacillus toebii showed growth within the temperature range of $45-70^{\circ} \mathrm{C}$ with optimum growth at $60^{\circ} \mathrm{C}$ (Sung et al. 2002). Geobacillus sp. strain GWE1 showed growth within the temperature range of $60-80^{\circ} \mathrm{C}$ while optimum growth was observed at $70^{\circ} \mathrm{C}$ (Daniela et al. 2013). G. thermoleovorans DA2 isolated from Southern Sinai, Egypt was able to grow within the temperature range of $50-80^{\circ} \mathrm{C}$ displaying optimal growth at $65 \circ \mathrm{C}$ (Fotouh et al. 2016). Geobacillus thermoleorans strain Rekadwadsis also showed optimal growth at $65^{\circ} \mathrm{C}$ (Rekadwad 2015). 


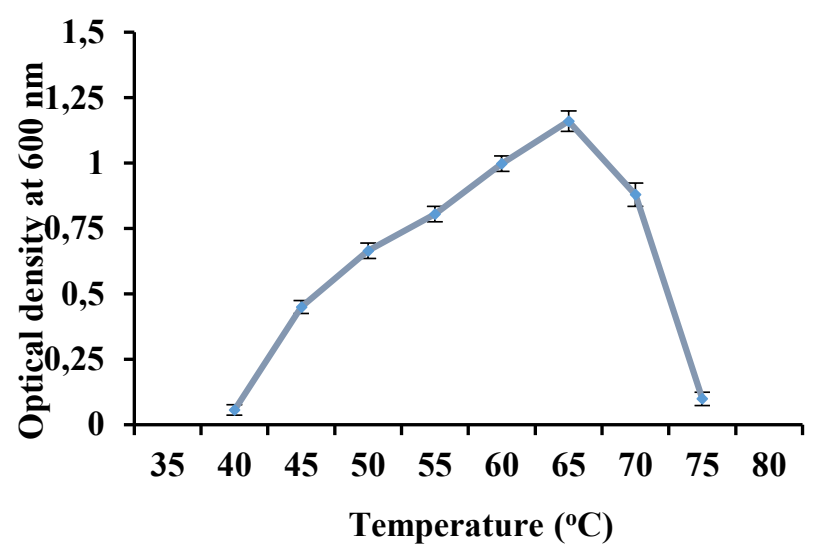

Figure4: Effect of temperature on the growth of isolate TP-2. \pm shows the standard deviation among the three parallel replicates.

Isolate TP-2 displayed growth at $\mathrm{NaCl}$ concentrations ranging from $0-3.5 \%$ while optimal growth was observed at $0.5 \% \mathrm{NaCl}$ concentration (Fig. 5). Geobacillus sp. isolated from a hot spring in Gilgit grew optimally in the absence of $\mathrm{NaCl}$ while it was incapable of growing at $5 \% \mathrm{NaCl}$ (Tayyab et al. 2011). G. vulcani and $G$. thermodenitrificans exhibited growth at $\mathrm{NaCl}$ concentration (0-3.0\%) whereas G. uzenensis and G. thermocatenulatus displayed growth at $\mathrm{NaCl}$ concentration (0-4\%) (Golovacheva et al. 1975; Suzuki et al. 1983; Caccamo et al. 2000; Nazina et al. 2001). Geobacillus sp. SG 01 presented growth at $\mathrm{NaCl}$ concentration (0-2\%) with optimal growth at $1 \% \mathrm{NaCl}$ (Yang et al. 2013). Geobacillus pallidus $\mathrm{p} 26$ grew within the $\mathrm{NaCl}$ range of $2-5 \%$ (Celik et al. 2014).

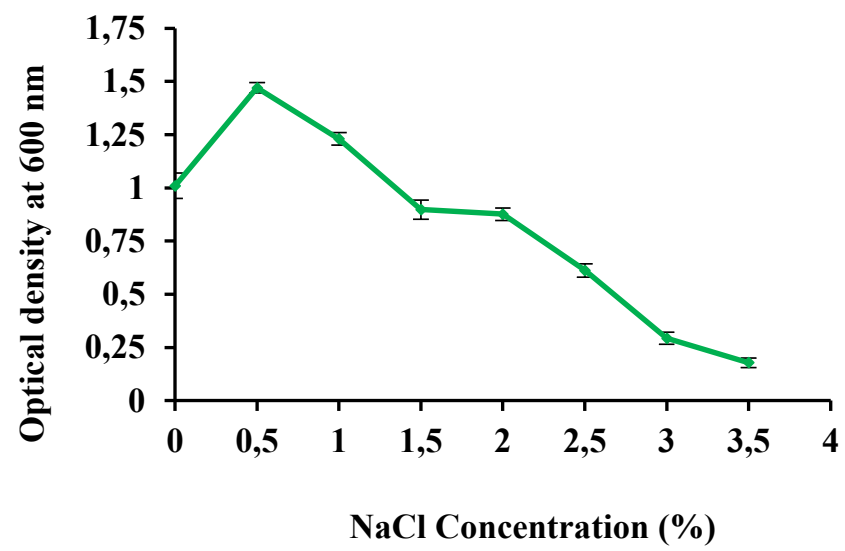

Figure 5: Effect of $\mathrm{NaCl}$ concentration on the growth of isolate TP-2. \pm indicates the standard deviation among the three parallel replicates.
Isolate TP-2 was catalase and oxidase positive. Biochemical characterization of the isolate using QTS-20 test strips revealed that isolate TP-2 gave positive result for gelatin hydrolysis, orthonitrophenyl $\beta$-D-galactopyranoside (ONPG), nitrate reduction and produced acid from sucrose, maltose and glucose while gave negative results for other tests such as tryptophan deaminase, sodium malonate, sodium citrate, indole production, lysine decarboxlase, ornithine decarboxylase, urea hydrolysis, $\mathrm{H}_{2} \mathrm{~S}$ production, arginine dihydrolase, acetoin production (VP), and acid production from sorbitol, arabinose, mannose, inositol and rhamnose following incubation at $65^{\circ} \mathrm{C}$ for 24 to $48 \mathrm{~h}$. Geobacillus toebii HBB-218 isolated from hot spring in Turkey and Geobacillus thermoleorans Strain Rekadwadsis isolated from Unkeshwar hot spring were found to be catalase and oxidase positive (Ozdemir and Biyik 2012; Rekadwad 2015)

Several carbon sources i.e., glucose, lactose, fructose, sucrose, maltose, starch, xylan, wheat bran extract and carboxymethylcellulose (CMC), at a final concentration of $1 \%(\mathrm{w} / \mathrm{v})$ and filter paper $(0.05 \mathrm{~g})$ were also screened for their ability to support the growth of the isolate in mineral salt medium after $48 \mathrm{~h}$ of incubation at $65^{\circ} \mathrm{C}$ (Fig. 6).

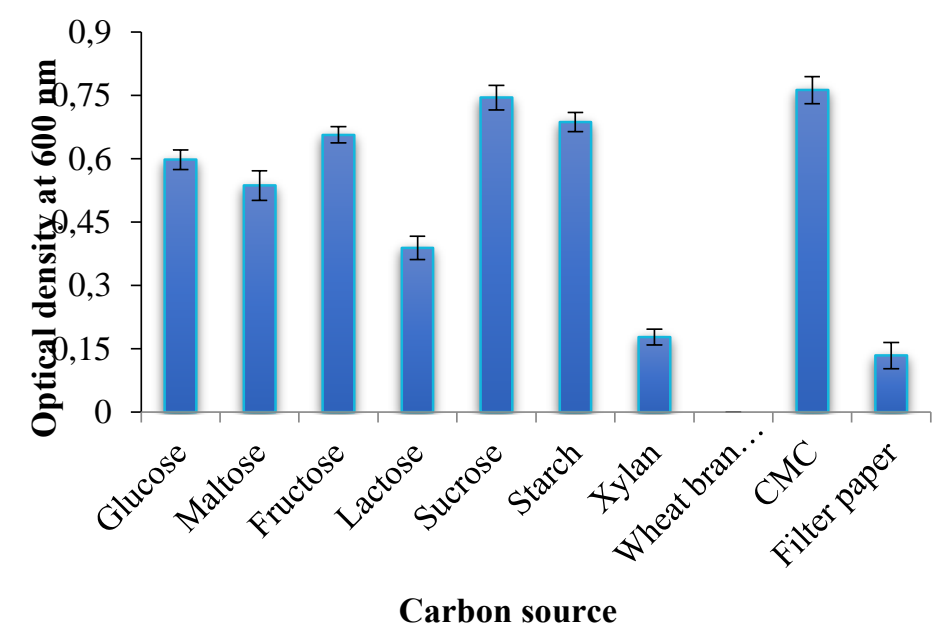

Figure 6: Growth of isolate TP-2 on different substrates. \pm indicates the standard deviation among the three parallel replicates.

Results showed that the isolate showed good growth on all the carbohydrates tested as sole carbon source except wheat bran extract. Maximum growth of the isolate was observed on CMC amended mineral salt medium followed by sucrose and starch. The ability of the isolate to degrade different carbohydrates could be explained by 
inclination of microbial societies toward living at low organic content in such environments and development of adjustable systems for uptake of any available food (Derekova et al. 2008). Examination of carbohydrate degrading activity of the isolate demonstrated that the isolate could be considered as possible source of biotechnologically valuable enzymes such as cellulases, amylase and xylanase. G. thermodenitrificans SG-01, SG-02 and SG-03 gave positive result for utilization of fructose, fructose and sucrose and sucrose, respectively (Yang et al. 2013). However, Geobacillus sp. strain GWE1 was unable to grow on fructose and xylan (Daniela et al. 2013). Geobacillus sp. NMS2 was able to ferment glucose, sucrose, maltose and lactose (Mathew and Rathnayake 2014). G. thermoleorans strain Rekadwadsis utilized fructose, lactose, sucrose and maltose as carbon source (Rekadwad 2015).

Genomic DNA was isolated from the isolate TP-2 and utilized for the amplification of 16S rRNA gene fragment using $9 \mathrm{~F}$ and $1510 \mathrm{R}$ primers. The purified 16S rRNA gene fragment was successfully recovered for TP-2 (Fig. 7). The purified PCR product was approximately $1.5 \mathrm{~kb}$ in size corresponding to the group of bacteria. Partial sequence of 16S rRNA gene fragment (936 bp) was obtained for TP-2 using an automated sequencer. 16S rRNA gene sequence analysis indicated that the isolate was distantly related to thermophilic Geobacillus group and the 16S rRNA gene sequence was quite distinct from the data available in the databases. The partial 16S rRNA gene sequence showed a similarity of $89 \%$ to Geobacillus debilis and $83 \%$ similarity to Geobacillus thermoglucosidasius and Geobacillus toebii (Fig. 8). Geobacillus debilis is a Gram negative bacterium that does not utilize starch. It is incapable of producing acid from sucrose, maltose and glucose but few strains give acid from arabinose and mannitol. It displayed growth within narrow temperature range of $50-75^{\circ} \mathrm{C}$ as compared isolate TP-2 $\left(45-75^{\circ} \mathrm{C}\right)$ and gave positive result for arginine dihydrolase. Moreover, the cells of isolate TP-2 were smaller in diameter $(0.2-0.3 \mu \mathrm{m})$ as compared to G. debilis $(0.5-1.0 \mu \mathrm{m})$ (Banat et al. 2004) (Table 2). Geobacillus thermoglucosidasius produces acid from mannitol, inositol, sorbitol and rhamnose and is urease positive. It does not hydrolyze gelatin. Geobacillus toebii does not hydrolyze starch and gelatin and produces acid from inositol (Suzuki et al. 1983; Priest et al. 1988; White et al. 1993; Caccamo et al. 2000; Sung et al. 2002; Banat et al. 2004).

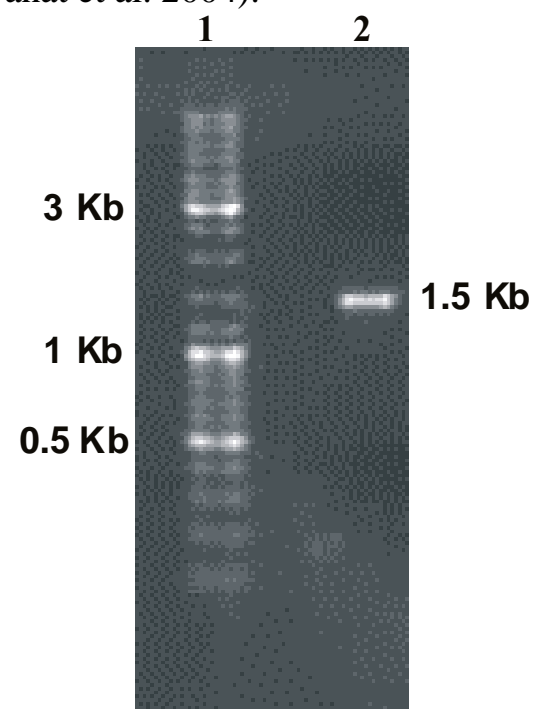

Fig. 7: Purified 16S rRNA gene fragment of the isolate TP-2. Lane 1 ladder, lane 2 purified 16S rRNA gene

A phylogenetic tree made by aligning $16 \mathrm{~S}$ rRNA gene sequences of type strains taken from GenBank, NCBI and sequence of the isolate TP-2 displayed similar relationship (Fig. 9). The separated phylogenetic relationship, low sequence homology and distinct phenotypic and biochemical characteristics of isolate TP-2 that were not confined to any specific group in the phylum Firmicutes suggest that it may indicate a novel strain. 


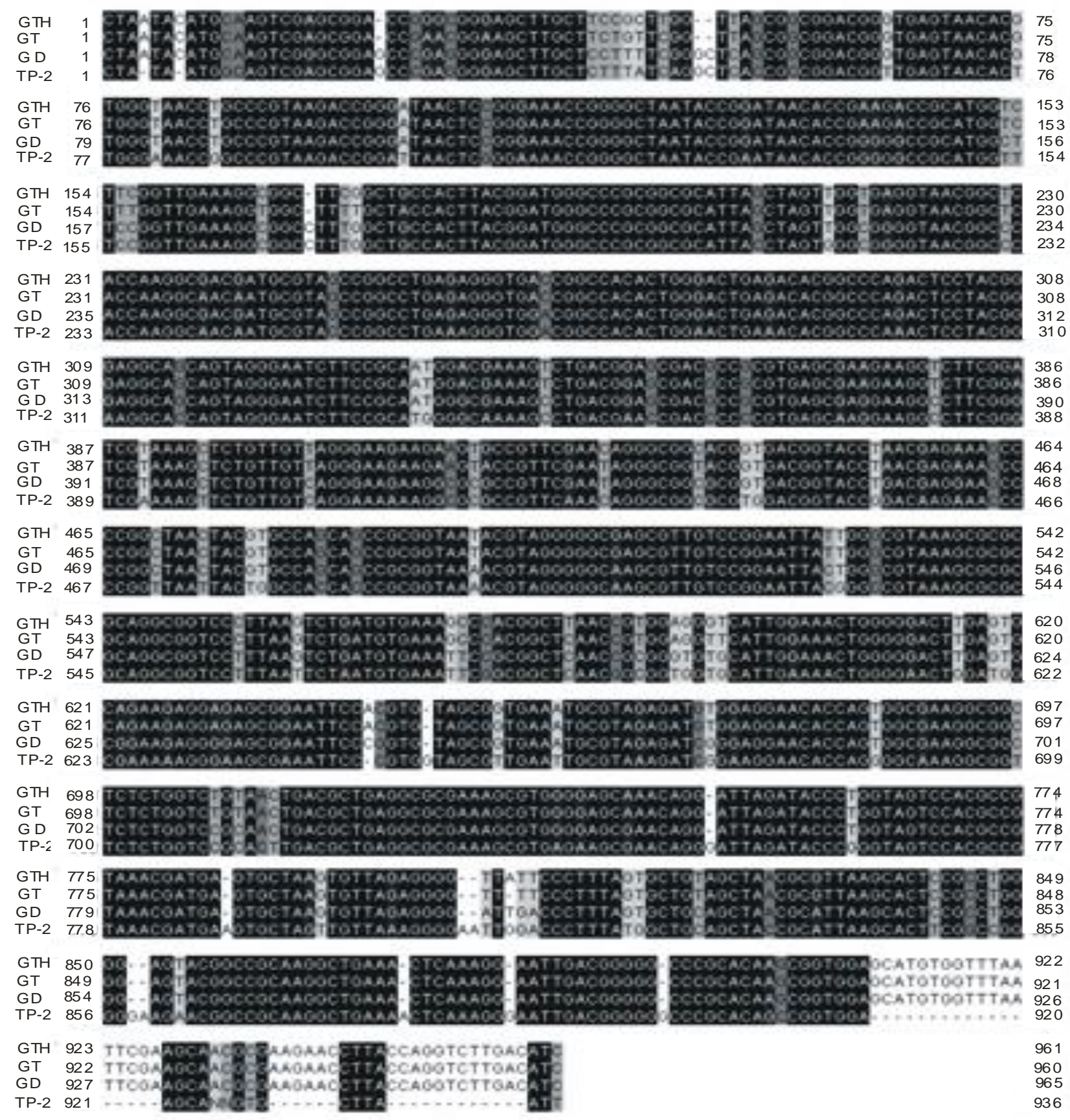

Figure8. Jalview representation of multiple sequence alignment of isolate TP-2 16S rRNA gene partial sequence with 16S rRNA gene sequences of closely related strains. GTH, Geobacillus thermoglucosidasius; GT, Geobacillus toebii; GD, Geobacillus debilis; TP-2, Isolate from the present study. Black shaded areas indicate identities in all sequences whereas other identities are presented as grey shaded areas. 
Table 2: Comparison of characteristics of isolated strain (TP-2) with other related strains

\begin{tabular}{|c|c|c|c|}
\hline Characteristics & $\begin{array}{l}\text { Isolate TP-2 } \\
\text { (This study) }\end{array}$ & $\begin{array}{c}\text { Geobacillus } \\
\text { sp. strain } \\
\text { GWE* }\end{array}$ & $\underset{\text { debilis }}{\boldsymbol{G}}$ \\
\hline Cell length $(\mu \mathrm{m})$ & 2.1-3.6 & 0.8 & $1.0-14.2$ \\
\hline Cell width $(\mu \mathrm{m})$ & $0.2-0.3$ & 0.1 & $0.5-1.0$ \\
\hline Motility & + & - & + \\
\hline Temperature range $\left({ }^{\circ} \mathrm{C}\right)$ & $45-75$ & $60-80$ & $50-70$ \\
\hline pH range & $5.5-8.5$ & 3.0-8.0 & ND \\
\hline $\mathrm{NaCl}$ range $(\%)$ & $0-3.5$ & 0-2 & ND \\
\hline Catalase & + & ND & ND \\
\hline Oxidase & + & - & ND \\
\hline Grams Reaction & + & + & - \\
\hline ONPG & + & ND & + \\
\hline Sodium citrate & - & ND & - \\
\hline Lysine dehydrogenase & - & ND & - \\
\hline Arginine dihydrolase & - & ND & + \\
\hline $\begin{array}{l}\text { Ornithine } \\
\text { decarboxylase }\end{array}$ & - & ND & - \\
\hline $\mathrm{H}_{2} \mathrm{~S}$ production & - & ND & - \\
\hline Urea hydrolysis & - & ND & - \\
\hline Acetoin production & - & ND & - \\
\hline Gelatin hydrolysis & + & - & d \\
\hline Nitrate Reduction & + & + & - \\
\hline Acid Production from & & & \\
\hline Glucose & + & + & - \\
\hline Maltose & + & - & - \\
\hline Sucrose & + & ND & - \\
\hline Mannose & - & - & - \\
\hline Arabinose & - & $+^{\mathrm{w}}$ & $d^{w}$ \\
\hline Rhamnose & - & ND & - \\
\hline Sorbitol & - & ND & $\mathbf{d} / \mathbf{w}$ \\
\hline Inositol & - & ND & - \\
\hline
\end{tabular}

+ , positive; - negative; ND, not determined, $+{ }^{\mathrm{w}}$ weakly positive; $\mathrm{d}$, positive in some strains *Daniela et al. (2013); ${ }^{€}$ Banat et al. (2004) 


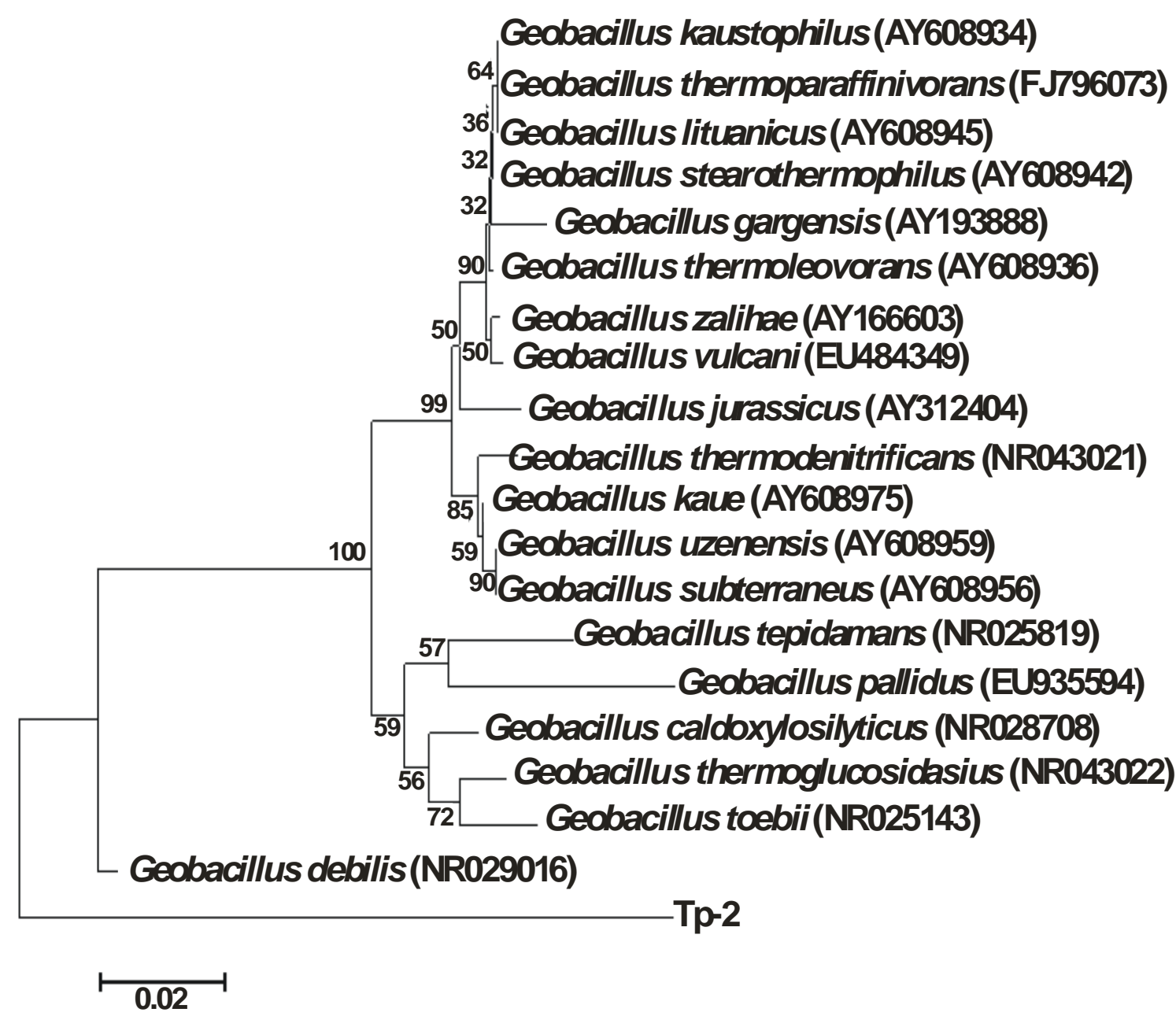

Figure 9: Phylogenetic tree showing evolutionary relationship between isolated strain and some reference strains. The number at the branch nodes indicates bootstrap values (\%) built on 1000 replications. The accession numbers are shown in parentheses. The scale bar denotes 0.02 nucleotide substitutes per position.

Thermophiles are modified to live at high temperature in hot springs. These microorganisms synthesize characteristic biocatalysts that work under extreme conditions analogous to those predominant in numerous industrial processes. Enzymes from thermophiles, hence, have found great attention in industrial applications (Haki and Rakslit 2003). Isolate TP-2 gave significant production of extracellular enzymes such as $\alpha$ amylase (0.654 U/ml/min), CMCase (0.086 $\mathrm{U} / \mathrm{ml} / \mathrm{min})$, FPase $(0.008 \mathrm{U} / \mathrm{ml} / \mathrm{min})$, Xylanase $\left(0.475 \mathrm{U} \mathrm{ml}^{-1} \mathrm{~min}^{-1}\right)$, Protease $\left(0.089 \mathrm{U} \mathrm{ml}^{-1} \mathrm{~min}^{-1}\right)$ and Lipase $\left(0.21 \mathrm{U} \mathrm{ml}^{-1} \mathrm{~min}^{-1}\right)$. Isolate TP-2 also gave intracellular production of CMCase $(0.017 \mathrm{U}$ $\left.\mathrm{g}^{-1} \mathrm{~min}^{-1}\right)$ and FPase $\left(0.003 \mathrm{U} \mathrm{g}^{-1} \mathrm{~min}^{-1}\right)$. Information about the production of enzymes by Geobacillus sp. is scarce and no work has been published regarding the production of these enzymes by G. debilis. G. thermoleovorans DA2 produced thermoalkaliphilic lipase that was optimally active at $60^{\circ} \mathrm{C}$ (Fotouh et al. 2016). Geobacillus thermoleorans strain Rekadwadsis produced extracellular amylase (8, $578 \mathrm{U} / \mathrm{mL}$ ) that was optimally active at $68^{\circ} \mathrm{C}$. Geobacillus kaustophilus PW11, Geobacillus toebii PW12, Geobacillus thermoleovorans PW13 and Geobacillus toebii PS4 isolated from Tattapani hotspring of Himachal Pradesh, India gave extracellular cellulase activity that was optimum at $80-90^{\circ} \mathrm{C}$ and $\mathrm{pH}$ 6.0-8.0 (Sharma et al. 2015). The lipase activity given by isolate TP-2 was more than the maximum lipase activity $\left(0.3 \mathrm{U} \mathrm{L}^{-1}\right)$ given by the thermophilic Bacillus sp. IHI-91(Becker et al. 1997) and maximum lipase activity $\left(0.15 \mathrm{U} \mathrm{ml}^{-1}\right)$, reported for Geobacillus zalihae T1 (Rahman et al. 2007). Extracellular xylanase and CMCase activities of isolate TP-2 were higher than the 
xylanase activities (300-400 U/L) reported for $G$. thermoleovorans (Sharma et al. 2007) and CMCase/cellulose activities reported for Geobacillus sp. even under optimized conditions (Tai et al. 2004; Abdel-Fattah et al. 2007; Rastogi et al. 2009). The thermophilic nature of isolate TP2 , profiling of the bacterial carbohydrates metabolism and significant production of industrially important enzymes makes it an interesting candidate for biotechnological applications.

\section{CONCLUSION}

Isolate TP-2 isolated from Tatta Pani hot springs is a highly potent strain that give significant production of enzymes i.e., $\alpha$-amylase, lipase, protease, CMCase, xylanase and FPase making it a promising strain for use in industries because of its industrially important thermostable enzymes.

\section{REFERENCES}

Abdel-Fattah YR, El-Helow ER, Ghanem KM, Lotfy WA. Application of factorial designs for optimization of avicelase production by a thermophilic Geobacillus isolate. Res J Microbiol. 2007; 2: 13-23.

Altschul SF, Gish W, Miller W, Myers EW, Lipman DJ. Basic local alignment search tool. J Mol Biol. 1990; 215: 403-10.

Bailey MJ, Biely P, Poutanen K. Interlaboratory testing of methods for assay of xylanase activity. J Biotechnol. 1992; 23: 257-70.

Banat IM, Roger M, Rahman TJ. Geobacillus debilis sp. nov., a novel obligately thermophilic bacterium isolated from a cool soil environment, and reassignment of Bacillus pallidus to Geobacillus pallidus comb. nov. Int J Syst Evol Microbiol. 2004; 54: 2197-2201.

Becker P, Abu-Reesh I, Markossian S. Determination of the kinetic parameters during continuous cultivation of the lipase producing thermophile Bacillus sp. IHI91 on olive oil. Appl Microbiol Biotechnol. 1997; 48: 184-90.

Beg QK, Bhushan B, Kapoor M, Hoondal GS. Production and characterization of thermostable xylanase and pectinase from Streptomyces sp. QG11-3. J Ind Microbiol Biotechnol. 2000; 24: 396-402.

Boomer SM, Noll KL, Geesey GG, Dutton BE. Formation of multilayered photosynthetic biofilms in an alkaline thermal spring in Yellowstone National Park, WY, USA. Appl Environ Microbiol. 2009; 75: 2464-75.
Caccamo D, Gugliandolo C, Stackebrandt E, Maugeri TL. Bacillus vulcani sp. nov., a novel thermophilic species isolated from a shallow marine hydrothermal vent. Int J Syst Evol Microbiol. 2000; 50: 2009-12.

Celik SY, Demir N, Demir Y, Adiguzel A, Gulluce M. Production of pectin lyase from Geobacillus pallidus p26, purification, characterization and fruit juice application. Acta Chimica Slovaca, 2014; 7(1): 5763.

Chen XG, Stabnikova O, Tay JH, Wang JY, Tay ST. Thermoactive extracellular proteases of Geobacillus caldoproteolyticus, sp. nov., from sewage sludge. Extremophiles, 2009; 8(6): 489-98.

Daniela CL, Linton JL, Munoz PA, Castro M, Boehmwald F. Characterization of the Thermophilic Bacterium Geobacillus sp. Strain GWE1 Isolated from a Sterilization Oven. Korean. J Microbiol biotechnol. 2013; 41(3): 278-283.

Demirjian D, Moris-Varas F, Cassidy C. Enzymes from extremophiles. Curr Opin Chem Biol. 2001; 5: 144 51.

Derekova A, Mandeva R, Kambourova M. Phylogenetic diversity of thermophilic carbohydrate degrading bacilli from Bulgarian hot springs. World J Microbiol Biotechnol. 2008; 24: 1697-702.

Fotouh DMA, Bayoumi RA and Hassan MA. Production of Thermoalkaliphilic Lipase from Geobacillus thermoleovorans DA2 and Application in Leather Industry. Enzyme Res. 2016; http://dx.doi.org/10.1155/2016/9034364

Ghose TK. Measurement of cellulase activities. Pure Appl Chem. 1987; 59: 257-68.

Golovacheva RS, Loginova LG, Salokhov TA, Kolesnikov AA, Zaitseva GN. A new thermophilic species, Bacillus thermocatenulatus nov. sp. Microbiology, 1975; 44: 230-3.

Gul-Guven R, Guven K, Poli A, Nicolaus B. Anoxybacillus kamchatkensis subsp. asaccharedens subsp. nov., a thermophilic bacterium isolated from a hot spring in Batman. J Gen Appl Microbiol. 2008; 54: 327-34.

Haki GD, Rakslit SK. Developments in industrially important thermostable enzymes: a review. Bioresour Technol. 2003; 89: 17-34.

Harland BF, Harland J. Fermentative reduction of phytic acid in rye, wheat and whole wheat bread. Cereal Chem. 1980; 57(3): 226-9.

Heinonen JK, Lahti RJ. A new and convenient colorimetric determination of inorganic orthophosphate and its application to the assay of inorganic pyrophosphatase. Anal Biochem. 1981; 113: 313-7.

Kauze T, Okuno M, Furumoto M, Watanabe $\mathrm{H}$. Biomineralization of pisoliths in hot springs. Mat Sci Engr. 2006; 26(4): 617-23.

Khalil A. Isolation and characterization of three thermophilic bacterial strains (lipase, cellulose and 
amylase producers) from hot springs in Saudi Arabia. Afr J Biotechnol. 2011; 10(44): 8834-9.

Khalil A, Salim M, Sallal AK. Enumeration of thermotolerant bacteria from recreational thermal ponds in Jordan. Cytobios. 1998; 96: 57-63.

Khan R, Shah SH, Khan NA. Investigation of the geothermal springs of the Tatta Pani area, district Kotli, Azad Jammu \& Kashmir. Geol. Surv. Pak., I.R., 1999; 701: 1-11.

Kim Y-O, Kim H-K, Bae K-S, Yu J-H, Oh T-K. Purification and properties of a thermostable phytase from Bacillus sp. DS11. Enzyme Microb. Technol., 1998; 22: 2-7.

Kronstad JW, Schnepf E, Whiteley HR. Diversity of location for Bacillus thuringiensis crystal protein genes. J Bacteriol. 1983; 154: 419-28.

Lau MC., Aitchison JC, Pointing SB. Bacterial community composition in thermophilic microbial mats from five hot springs in central Tibet. Extremophiles, 2009; 13: 139-49.

Lebedinsky AV, Chernyh NA, Bonch-Osmolovskaya EA. Phylogenetic systematics of microorganisms inhabiting thermal environments. Biochemistry (Mosc), 2007; 72(12): 1299-312.

Lee DW, Koh YS, Kim KJ, Kim BC, Choi HJ, Kim DS et al. Isolation and characterization of a thermophilic lipase from Bacillus thermoleovorans ID-1. FEMS Microbiol Lett. 1999; 179: 393-400.

Macfaddin JF. Biochemical tests identification for of medical bacteria. 3 ed. Lippincott Williams and Wilkins, 2000.

Mandels M, Andreotti R, Roche C. Measurement of saccharifying cellulose. Biotechnol Bioeng Symp. 1976; 6: 21-3.

Mandels M, Reese ET. Induction of cellulase in Trichoderma viride as influenced by carbon sources and metals. J Bacteriol. 1957; 73: 269-78.

Marteinsson VT, Hauksdottir S, Hobel CFV, Kristmannsdottir H, Hreggvidsson GO, Kristjansson JK. Phylogenetic diversity analysis of subterranean hot springs in Iceland. Appl Environ Microbiol. 2001; 67: 4242-8.

Mathew CD, Rathnayake S. Isolation and characterization of alpha amylase isolated from a hot water spring in Sri Lanka. Int J Microbiol Res. 2014; 5(4): 50-61.

Maugeri TL, Gugliandolo C, Caccamo D, Stackebrandt E. A polyphasic taxonomic study of thermophilic bacilli from shallow, marine vents. Syst Appl Microbiol. 2001; 24: 572-87.

McDonald CE, Chen LL. Lowry modification of the Folin reagent for determination of proteinase activity. Ann Biochem. 1965; 10: 175.

Mustranta A. Use of lipase in the resolution of raceme ibuprofen. Appl Microbiol Biotechnol. 1992; 38: 616.
Nair PS, Surendran PK. Biochemical characterization of lactic acid bacteria isolated from fish and prawn. $\mathbf{J}$ Cutt Col. 2004; 4: 48-52.

Narayan VV, Hatha MA, Morgan HW, Rao D. Isolation and characterization of aerobic thermophilic bacteria from Savusavu hot spring in Fiji. Microbes Environ. 2008; 23(4): 350-2.

Nazina TN, Tourova TP, Poltaraus AB, Novikova EV, Grigoryan AA, Ivanova AE. et al. Taxonomic study of aerobic thermophilic bacilli: descriptions of Geobacillus subterraneus gen. nov., sp. nov. and Geobacillus uzenensis sp. nov. from petroleum reservoirs and transfer of Bacillus stearothermophilus, Bacillus thermocatenulatus, Bacillus thermoleovorans, Bacillus kaustophilus, Bacillus thermoglucosidasius and Bacillus thermodenitrificans to Geobacillus as the new combinations G. stearothermophilus, $G$. thermocatenulatus, $G$. thermoleovorans, $G$. kaustophilus, $G$. thermoglucosidasius and $G$. thermodenitrificans. Int J Syst Evol Microbiol. 2001; 51: 433-46.

Ozdemir GB, Biyik HH. Isolation and characterization of toebicin 218, a bacteriocin, produced by Geobacillus toebii HBB-218. Afr J Biotechnol. 2012; 11(30): 7711-19.

Priest FG, Goodfellow M, Todd C. A numerical classification of the genus Bacillus. J Gen Microbiol. 1988; 134: 1847-82.

Rahman RZ, Leow TC, Salleh A, Basri M. Geobacillus zalihae sp. nov., a thermophilic lipolytic bacterium isolated from palm oil mill effluent in Malaysia. BMC Microbiol. 2007; 7: 77-87.

Rahman TJ, Marchant R, Banat IM. Distribution and molecular investigation of highly thermophilic bacteria associated with cool soil environments. Biochem Soc Trans. 2004; 32: 209-13.

Rekadwad BN. Characterization of Amylase from Industrially Important Thermophilic Microorganism: Geobacillus thermoleovorans Strain Rekadwadsis. Int J Life Biotechnol Pharma Res. 2015; 4(1): 26-29.

Rastogi G, Muppidi GL, Gurram RN, Adhikari A, Bischoff KM, Hughes SR. Isolation and characterization of cellulose-degrading bacteria from the deep subsurface of the Homestake gold mine, Lead, South Dakota, USA. J Ind Microbiol Biotechnol. 2009; 36: 585-98.

Reysenbach AL, Ehringer M, Hershberger K. Microbial diversity at $83^{\circ} \mathrm{C}$ in the calcite springs, Yellowstone National Park: another environment where the Aquificales and "Korarchaeota" coexist. Extremophiles, 2000; 4: 61-7.

Rick W, Stegbauer HP. $\alpha$-Amylase measurement of reducing groups. In: Bergmeyer HV, editor. Methods of enzymatic analysis. 2 ed. New York: Academic Press; 1974. 
Saitou N, Nei M. The neighbor-joining method: A new method for reconstructing phylogenetic trees. Mol Biol Evol. 1987; 4: 406-25.

Sharma A, Adhikari S, Satyanarayana T. Alkalithermostable and cellulase-free xylanase production by an extreme thermophile Geobacillus thermoleovorans. World J Microbiol Biotechnol. 2007; 23: 483-90.

Sharma P, Gupta S, Sourirajan A, Dev K. Characterization of extracellular thermophillic cellulase from thermophilic Geobacillus sp. isolated from Tattapani Hot spring of Himachal Pradesh, India. Int J Adv Biotech Res. 2015; 6(3): 433-42.

Sharma A, Pandey A, Shouche YS, Kumar B, Kulkarni G. Characterization and identification of Geobacillus spp. isolated from Soldhar hot spring site of Garhwal Himalaya, India. J Basic Microbiol. 2009; 48: 1-8.

Sievert SM, Ziebis W, Kuever J, Sahm K. Relative abundance of Archaea and Bacteria along a thermal gradient of a shallow water hydrothermal vent quantified by rRNA slot-blot hybridization. Microbiology, 2000; 146: 1287-93.

Snedecor G, Cochrane WG. Statistical Methods. 7 ed., Iowa State Univ; 1980.

Srivastava RA, Baruah JN. Culture conditions for production of thermostable amylase by Bacillus stearothermophilus. Appl Environ Microbiol. 1986; 52(1): 179-84.

Sung M-H, Kim H, Bae J-W, Rhee S-K, Jeon CO, Kim $\mathrm{K}$, et al. Geobacillus toebii sp. nov., a novel thermophilic bacterium isolated from hay compost. Int J Syst Evol Microbiol. 2002; 52: 2251-5.

Suzuki Y, Kishigami T, Inoue K, Mizoguchi Y, Eto N, Takagi M, Abe S. Bacillus thermoglucosidasius sp. nov., a new species of obligately thermophilic bacilli. Syst Appl Microbiol. 1983; 4: 487-95.

Tai SK, Lin HP, Kuo J, Liu JK. Isolation and characterization of a cellulolytic Geobacillus thermoleovorans T4 strain from sugar refinery wastewater. Extremophiles, 2004; 8(5): 345-9.

Tamura K, Peterson D, Peterson N, Stecher G, Nei M, Kumar S. MEGA5: Molecular evolutionary genetics analysis using maximum likelihood, evolutionary distance, and maximum parsimony methods. Mol Biol Evol. 2011; 28: 2731-9.

Tarrand JJ, Groschel DHM. Rapid, modified oxidase test for oxidase variable bacterial isolates. J Clin Microbiol. 1982; 16: 772-4.

Tayyab M, Rashid N, Akhtar M. Isolation and identification of lipase producing thermophilic Geobacillus sp. SBS-4S: Cloning and characterization of the lipase. J Biosci Bioeng. 2011; 111(3): 272-8.

Thompson JD, Higgins DG, Gibson TJ. CLUSTALW: Improving the sensitivity of progressive multiple sequence alignment through sequence weighting position-specific gap penalties and weight matrix choice. Nucleic Acids Res. 1994; 22: 4673-80.
Waterhouse AM, Procter JB, Martin DM, Clamp M, Barton GJ. Jalview Version 2 - a multiple sequence alignment editor and analysis workbench. Bioinformatics, 2009; 25: 1189-91.

White D, Sharp RJ, Priest FG. A polyphasic taxonomic study of thermophilic bacilli from a wide geographical area. Antonie van Leeuwenhoek, 1993 ; 64: 357-86.

Wiegel J, Ljungdahl LG. Thermoanaerobacter ethanolicus gen. nov., sp. nov., a new extreme thermophilic, anaerobic bacterium. Arch Microbiol. 1981; 128: 343-8.

Wissuwa, J. Stokke R, Fedoy AE, Lian K, Smalas AO, Steen IH. Isolation and complete genome sequence of the thermophilicGeobacillus sp. 12AMOR1 from an Arctic deep-sea hydrothermal vent site. Stand Genomic Sci, 2016; 11(16): DOI 10.1186/s40793-016-0137$\mathrm{y}$.

Yang SH, Cho JK, Lee SY, Abanto OD, Kim SK, Ghosh C, Lim JS, Hwang SG. Isolation and Characterization of Novel Denitrifying Bacterium Geobacillus sp. SG-01 Strain from Wood Chips Composted with Swine Manure. Asian Australas J Anim Sci. 2013; 26(11): 1651-58.
Received: May 07, 2016; Accepted: June 01, 2016 


\section{Erratum}

In Article "Characterization Of A Novel Hydrolytic Enzyme Producing Thermophilic Bacterium Isolated From The Hot Spring Of Azad Kashmir-Pakistan", with the number of DOI: http://dx.doi.org/10.1590/1678-4324-2016150662, published in journal Brazilian Archives of Biology and Technology, vol. 59, the 01 page.

That read:

"Sana Zahoor ${ }^{1 *}$; Huhammad Mohsin Javed²; Masroor Ellahi Babar "."

Read:

"Sana Zahoor ${ }^{1 *}$; Muhammad Mohsin Javed ${ }^{2}$; Masroor Ellahi Babarl ."

In the 01 page.

That read:

“11Authors for correspondence: azzamohamed99@yahoo.com”

Read:

“11 Authors for correspondence: sanazahur@yahoo.com” 